\title{
The reformed identity and mission from the margins
}

\author{
Hewitt, Roderick \\ University of KwaZulu-Natal \\ hewitt@ukzn.ac.za
}

\begin{abstract}
This paper interrogates the reformed identity that has been bequeathed through the Reformation and appropriated by the contemporary church within the Global South, to determine the extent to which it affirms life for those that live on the margins. It postulates that the reformed identity as bequeathed by John Calvin and his school of thought, fashioned a reformed identify that was to a great extent, shaped through its missional engagement with people from the margins. Yet, within an era when European colonialism with reformed identity complicity expanded throughout the world, commoditizing, enslaving and de-humanizing lives, Calvin and his school failed to name and embrace the suffering of "the non-European others" as part of their reformed missional agenda. It argues also that in this postmodern era the reformed identity is experiencing "arrested missional development" because of its uncritical alliance with neoliberalism and neo-conservative socio-economic, political and theological discourses. Therefore, the notion that there can be a generic homogeneous reformed identity is questionable. The reality suggests contestations of multiple reformed identities. This has had far reaching consequences, especially for people who live on the margins who are experiencing many threats to life.
\end{abstract}

Key words

Reformed identity; mission, margins; neoliberalism; neo-conservatism; Global South

\section{Introduction}

In $2004 \mathrm{I}$ attended the 24th General Council of the World Alliance of Reformed Churches (WARC) in Accra, Ghana where the delegates adopted a statement in which they covenanted for justice in the global economy and the earth that became known as "The Accra Confession". ${ }^{1}$ The statement

1 The Accra Confession, 2010. Developed and published by the North American Covenanting for Justice Working Group, p. 4, [Online] Available: http://d3n8a8pro7vhmx. 
challenged the reformed faith community to respond "as a matter of faith in the gospel of Jesus Christ" to engage through their theological convictions, mission and witness for justice in the global economy and environment. During the event a historic visit was made to the infamous Elmina Castle that served as the transhipment port for millions of Africans who were enslaved and sold to the Portuguese - the founders of Elmina Castle (also called St. George's Castle). It is through this economic investment by the Portuguese that traded in the commodification of African lives through their blood, sweat, tears, labour, knowledge and intelligence that the modern foundations of Europe and the United States of America (USA) were established. From the ownership of Catholic Portuguese traders the castle was captured by reformed identity Dutch traders in 1637 who continued the slave trade until 1814 and later sold the asset in 1871 to the British.

The relevance of Elmina castle for this article is linked to the role that European Reformed Christianity played in the process of African enslavement. Above the dungeon that accommodated thousands of Africans chained and tightly packed like cargo whilst awaiting their turn to go through the "door of no return" to the Americas ${ }^{2}$ was the sanctuary of the Dutch Reformed Church where Sunday services for the colonial staff were held. From the dungeon where the African women were enslaved was the staircase that led up to the Governor's third floor dwelling. What struck me was the painting of the open Bible on the wall quoting from Psalm 132:13 "For the Lord has chosen Zion ..." Tears flowed down my cheeks as I was forced to face the dark epiphany of the human capacity for evil and how religion can be used to legitimize it. How, in God's name, could Reformed Christians for so many years, worshipped the sovereign God while directly below them human beings were suffering and crying out in pain? I arrived at the difficult conclusion that the reformed theological identity carries within it a propensity to legitimize what is evil if it delivers economic prosperity to the powerful elite class. In an environment that made acceptable human suffering for those deemed to be 'not fully human',

cloudfront.net/unitedchurchofchrist/legacy_url/6049/Accra-new-final.pdf?1418430421 [Accessed September 24, 2017].

2 Judith Graham, 1990. The Slave Fortresses of Ghana, [Online] Available: http:// www.nytimes.com/1990/11/25/travel/the-slave-fortresses-of-ghana.html?pagewanted=all\&mcubz=0 [Accessed October 1, 2017]. 
God was domesticated and nationalized to serve the colonial agenda. God had therefore chosen "for good", Elmina (their Zion) to be his home. Elmina left an indelible mark in my Reformed theological formation that warned against misuse of the Bible and the missional agenda of the church to legitimized oppression.

A contemporary signpost of this crisis came again in June 2017 through my participation in the World Communion of Reformed Churches' Global Institute of Theology (GIT) Summer School held in Wuppertal, Germany. In an exposure visit to the History Museum in Wuppertal ${ }^{3}$ with the students and staff of the Institute, we observed the context of the economic and social history of the industrialization in the valley of the Wupper between 1750 and 1900 through interactive displays. The displays illustrated how the foundations of Europe's industrialization were established from the economic benefits of planting and processing cotton that gave rise to the textile industry that furthermore resulted in the commoditization of Africans and their enslavement in the Americas and the abuse of labourers, especially child labour in the European textile factories. Again, the displays illustrated the contradiction within the reformed theological identity that, on one hand, put up fierce resistance against political and religious oppression and on the other hand, was complicit in colluding with economic oppressive forces that served the interest of the owners of industry against the working class. Finally, at the Ruhr Museum in Essen we experienced a unique presentation of the history of the Ruhr area. The display focused on the role that coal mining played in the social, religious and economic life of the people, especially the working class. The display also highlighted the rise of Hitler and the Third Reich in Germany and how ordinary citizens, including many reformed evangelical leaders and their churches, allowed themselves to be duped into blessing an evil system of governance, that in the name of nationalism, murdered millions of people on the margins. All of these exposures led me again to question what seems to be an inherent contradiction within the reformed identity. Therefore an important question that must be asked is: Is there an inherent dichotomy in the construct of Reformed identity/ies?

3 The Historical Centre (Fredrick Engles House and the Museum of Early Industrialisation), [Online] Available: http://www.erih.net/i-want-to-go-there/site/show/Sites/ historical-centre-engels-house-and-museum-of-early-industrialization/ [Accessed October 1, 2017]. 


\section{Reformed identity and hermeneutical vulnerability}

This articles does not seek the critique of reform theological arguments postulated by key scholars but rather to engage into a missional challenge the ways in which theological understanding and practice affect the lives of those that live on the margins of their society. What is termed as reformed identity has evolved out of ecclesial tradition that embraced a Christian thought system and praxis of the sixteenth-century Genevan reformation led by the French theologian John Calvin. ${ }^{4}$ His reformed theology emerged in response to his anger over the systemic denial of life from the religious, socio-political and economic structures of his context. Calvin's reforming work as a teacher attracted an international and culturally diverse community that included refugees and students, many of whom returned to their homelands to spread his teachings of the Christian faith and its missional implications for the identity, vocation and witness of the Church. According to Jane Dempsey Douglass,

"English-speaking Calvinist people have till today generally called themselves Presbyterians, after the form of government by presbyters (pastors and elders), the most common type of government in reformed churches. Most churches that descended from continental European reformed churches still retain the name reformed, and the term is also widely used to designate the whole family related to the Genevan reformation." ${ }^{5}$

However, even at this early development of the Reformed identity that was linked to European phase of colonization in the sixteenth century, Calvin's theology had signs of being embedded with missio-authoritarian approach with people who live on the margins of the feudal economy. The poor were not seen so much as active participants/partners in God's mission in Christ but passive objects/recipients in need of his teachings on God's favour. Therefore, the early seeds of contradiction were already sown within the construct of the classical reformed era through its inconsistent theological and missional approach to the plight of people that live on the margins of

4 Jane Dempsey Douglass, 1996. A Reformed Perspective on the Ecumenical Movement, [Online] Available: http://www.religion-online.org/showarticle.asp?title=421 [Accessed October 1,2017] p. 1.

5 Ibid., p. 3 
Europe. This was especially true with regards to the plight of the people that experienced European colonialism that resulted in the genocide of some of the indigenous American Indians and the commodification and enslavement of millions of Africans. Their anger against oppression was selectively applied. Out of the European reformed heritage has evolved diverse and multiple identities shaped by different contextual sociopolitical settings of the church's witness. Therefore, every definition of the term "reformed identity" offers a biased perspective from those whose interest is served by the church and by those who set the agenda and definition of the concept. Although the term "reformed" seems to suggest a fixed unchanging reality, the Dutch Reformed theologian Jodocus van Lodenstein in 1674, argued that ecclesia reformata semper reformanda ("the reformed Church should always be reforming itself"). 6 Therefore, the concept is contestable because of its dual ideological hermeneutics that is rooted in both certainty and uncertainty. What then is the phenomenon that shapes the reformed identity? Bediako argues that the question of identity is key in the understanding of the concerns of Christian theology, and in this case reformed theology, ${ }^{7}$ making a new interpretive paradigm to interrogate the phenomenon of identity imperative.

The radical nature of reformed theological identity posited by Calvin emerged from a hermeneutical lens that was informed though missional pedagogy and solidarity with common people, many of whom lived on the margins of their society. His teachings empowered the diverse international community of refugees and students to claim their role and to fully participate in the church's mission. The early expressions of the reformed identity as shaped by Calvin made use of various vernacular languages in worship, teaching and theological writings in order to equip the common people to participate in the mission of Christ through the church - the faith community where "the preaching of the Word of

6 Koffeman, L.J., 2015, "Ecclesia reformata semper reformanda, Church renewal from a Reformed perspective", HTS Teologiese Studies/Theological Studies 71(3), Art. \#2875, 5 pages. http://dx.doi.org/10.4102/ hts.v71i3.2875 [Online] Available: https://repository. up.ac.za/bitstream/handle/2263/50939/Koffeman_Ecclesia_2015.pdf;sequence=1 [Accessed October 4, 2017].

7 Bediako Kwame, 1999. Theology and Identity. Oxford: Regnum Books, pp. 1. 
God and the observance of the sacraments" ${ }^{\prime}$ are regularly observed. For Calvin, church membership meant full participation in the mission of God in Christ through the church and this called for the mobilization of the "Priesthood of all believers" to fulfil their different roles and offices. All of these expressions of the reformed faith were energized through theological discourse informed from solidarity with common people and their struggles to overcome threats to life:

Calvin's theological writings emerged from a social and cultural context that responded to the perceived threats to life in sixteenth century Europe. Therefore, his theology was contextual. However, the contemporary expression of the reformed identity within the Western world has not adequately contextualize or engage in effective local appropriation of the gospel to speak to its people and is therefore no longer perceived as relevant in responding to the threats to life. If the reformed identity is to experience missional transformation, it must risk engagement with the life struggles and challenges of ordinary people that live on the margins. The most powerful legacy bequeathed by the reformed heritage is its model of governance and ministry in which the clergy and elders play a central role. However for its missional purpose to be effectively appropriated, it must focus instead on its heritage of unprecedented revolutionary act of resistance, social and political insurgency, and individual uprising of conscience against religious, economic and political systems of corruption.

Reform mission in the past was understood as movement (geographically) from the centre to the periphery, from the privileged to the marginalised. Being at the centre meant that Reformed mission had access to privileges from the political and economic power systems at the centre that would result in missio-cultural contradiction. ${ }^{9}$ This meant that by aligning itself with those that possess privileges at the centre, the reformed identity was compromised and risked losing inculturative trust from those that lived on the margins.

8 Calvin, John 2002. Institutes of the Christian Religion Beveridge Henry (Translator), Christian Classics Ethereal Library, Grand Rapids, MI. [Online] Available: http://www. ccel.org/ccel/calvin/institutes.html

9 Hewitt, Church and Culture, pp.63 
The reformed transformational thinking about biblical exegesis bequeathed by Calvin and other Reformers lifted up the indispensable requirements of faith, authority of scripture and grace as fundamental ingredients of the Reformed faith/tradition that must be lived out contextually in the world. According to Brian Blount, reformed exegesis should therefore be contextual/cultural exegesis, ${ }^{10}$ because all of the world belongs to God and the Gospel must be communicated in all languages. Therefore, in exploring how the reformed theological identity can be expressed in the contemporary interpretive environment, it must be open to listening to marginalized cultures and their reading of scripture to discover how and where God is at work in their quest to overcome the threats to life.

\section{Reformed and always reforming (Semper reformanda)}

Being a survivor of those who were commoditized and trafficked across the Atlantic ocean (the holocaust site for millions of Africans) against their will to the Americas, I am conscious that through British colonialism, I became a beneficiary of another form of reformed missional praxis of "evangelization through education" (Scottish Presbyterians) that emerged through contradictory benefits from the oppressive system of colonialism and slavery and also a liberative contributor to emancipation. ${ }^{11}$ However, both the reformed theological identity of Calvin's era and that which has evolved in the contemporary era seem to confirm that they both possess life affirming and life-denying potentials that are triggered according to whether or not they enter into colluding relationships with economic and political ideologies that are life-denying, especially for those people that live on the margins. This paper therefore argues that the Achilles heel in the reformed theological identity lies in its inherent contradictory approach towards political and economic power systems and the view that the margins have nothing to offer to the mission of God in the world. This theological instrument of liberation loses its potency to facilitate justice for those that live on the margins when it proves unable through its

10 Brian K. Blount, 2007. Reading Contextually as Reading Reformed, in Wallace M. Alston Jr. \& Michael Welker (eds.), Reformed Theology, Identity and Ecumenicity II, Biblical Interpretation in the Reformed Tradition. William B. Eerdmans Publishing Company: Grand Rapids, Michigan, Cambridge: U.K. pp. 42.

11 Hewitt R. Roderick. 2012. Church and Culture, an Anglo-Caribbean Experience of Hybridity and Contradiction. Cluster Publications, Dorpspruit. pp. 65. 
relationship with power systems to keep its critical distance, and to know when to engage in critical solidarity. ${ }^{12}$

\section{Mission on the margins and the future of reformed identity}

The world is facing unchartered missional waters in which life threatening forces of nuclear war, climate change, economic and cultural globalization, the onslaught of secular and religious fundamentalism/extremism, lack of trust in political and religious leaders and the institutions that they represent, among others, invite the Reformed faith community to ask missional questions about its identity, vocation and witness. The strong emphasis of Western reformed theology on the transcendence of God, has weakened the balance on God's immanence ${ }^{13}$ to the point where it does not naturally lead the laity to active participation in human and environmental issues of justice that are usually experienced by people that live on the margins. This paper therefore affirms that the reformed identity needs renewal and this can best be done through rediscovering its solidarity with mission from the margins that affirms the missional identity of God (Missio Dei), according to Phillip Wickerei,

Missio Dei thinking emphasizes the radical activity of God in history, challenging liberals and conservatives, pietistic and "good works" ideas of mission ... God had been working in the world all the time, and in all places, creating and redeeming, liberating and saving, whether the churches in the West realized this or not. God's work in all cultures was seen to be part of salvation-history, challenging all human institutions, and provoking a crisis in the

12 Pillay, J., 2017. "Faith and reality: The role and contributions of the ecumenical church to the realities and development of South Africa since the advent of democracy in 1994”, HTS Teologiese Studies/Theological Studies 73(4), 4519, pp.1 https://doi.org/10.4102/ hts.v73i4.4519 [Accessed October 4, 2017]. The terms, "critical distance" and "critical solidarity" have being made popular in the South African Ecumenical community through proponents like Allan Boesak and Desmond Tutu to describe the nature of the church's relationship with the state.

13 Grenz, J, Stanley, \& Olson, E, Roger, 1992. 20th Century Theology - God and the World in a Transitional Age. InterVarsity Press, Illinois. pp. 15-50. Immanence as a concept speaks of God being similar to his creation subject to the same natural laws whereas transcendent acknowledges that God is different and exercise superior power over creation/nature and the created is restricted from direct approach to this deity because of his otherness, holiness and sovereign authority. 
church and its mission. Missio Dei called the triumphalism of the missionary movement all over the world to a prophetic judgment. ${ }^{14}$

I have therefore chosen the World Council of Churches (WCC) 2013 Mission statement, "Together towards Life" to converse with the reformed identity, because it has made the affirmation of life in abundance as the most urgent and essential element in the contemporary identity and witness of Christian mission. ${ }^{15}$

The triune God's saving work in the world as Creator, Redeemer and Sustainer of all life (John 20:21) is manifested in Jesus Christ as the Life of the World who incarnates God's love for all creation and Life. This understanding of mission includes non-human dimension of creation (justice, peace and integrity of creation). Therefore mission involves struggle and resistance in the quest for justice and inclusivity, healing and wholeness. ${ }^{16}$ Although the "concept mission from the margins" is controversial and prone to misrepresentation, because margins do not represent a homogenous group and the people can be objectified and categorized rather than recognized as being marginalized, because of unjust power structures utilized by those that live "at the centre" of power dynamics. In spite of these weaknesses the term has validity in describing a phenomenon that is real for many people in the South who are excluded from decision making processes to access many of their nation's resources. ${ }^{17}$

The term margins is best understood missiological within diakonia (servant ministry) as expressing solidarity and hospitality with the oppressed that embody and imitate what Obery Hendricks Jr describes as the "Politics

14 Wickeri, L, Philip 2004. Mission From The Margins: The Missio Dei in the Crisis of World Christianity. Presbyterian Church (U.S.A.), A Corporation, on behalf of the Office of Theology and Worship. Louisville, KY. pp. 8.

15 Keum J (ed.), 2012. Together Towards Life, World Council of Churches Publications, Geneva, pp. 4.

16 Ibid., pp. 15.

17 Kenneth Ross, Jooseop Keum, Kyriaki Avtzi and Roderick R. Hewitt 2016. Ecumenical Missiology Changing Landscape and New Conceptions of Mission, (Regnum Books, WCC Publications Oxford and Geneva) pp. 309-319. "Margins" by Deenabandhu Manchala; pp, 355-380 "Together Towards Life", The New WCC Affirmation on Mission and Evangelism; pp 419-428 "Together Towards Life: An Ecumenical Protestant Assessment" by Thomas Kemper. 
of Jesus". ${ }^{18}$ In the ministry of Jesus diakonia mission invites political engagement that involves taking strategic action to speak against injustice and fight for human dignity.

The margins or "the sinned against" are demonized by those at the centre to protect and prevent their position from being critically examined, ${ }^{19}$ because their structurally legitimized systems of power and wealth, that is built on greed, are designed to benefit the privileged few at the expense of the many. Therefore it could be argued that it is societal unjust structures that allow permission for violence against those that live on the margins, because they are considered to be "less normal human" such as, indigenous people, queer people, poor people, immigrants and women who usually live in a permanent state of vulnerability and maybe excluded for active participation in the political and economic decisions. Margins constitute a contested concrete existential realities/experiences within human and nonhuman existence and therefore is a category of missional imaginations. Finally, margins can also be an ever evolving reality - nations can be margins, races can be margins - they are never neutral spaces. They also feed on the ideology of the powerful to replicate marginalization from within their structures of power.

\section{The changing landscape of global Christianity}

Majority of Christians in the world, and that includes reformed Christians, are either living or have their origins in the global South and East. Migration has become a worldwide, multi-directional phenomenon. Emergence of strong Pentecostal and charismatic movements have resulted in ordinary people at the margins claiming their key role as agents of God's mission going from 'everywhere to everywhere'. Therefore, a radical re-thinking of the reformed Identity from the perspective of the global South where millions of people are living on the margins is needed. New subversive forms of reformed identities are emerging through South-South movements of ordinary people through migration of refugees and workers,

18 Hendricks, M, Obery, Jr. 2006. The Politics of Jesus. Doubleday: New York. pp. 132-167.

19 Deenabandhu Manchala 2012. Mission From The Margins, Toward a Just World, International Review of Mission, Geneva [Online] Available: http://onlinelibrary.wiley.com/ doi/10.1111/j.1758y6631.2012.00092.x/full 
founding new ecclesial communities without being led by official clergy and this is contributing to new models of evangelization, some being cultic and exploitative and others life-giving.

Hewitt states that "The term Global South has therefore emerged as a contemporary expression to describe how developing economies most of which are in the Southern hemisphere ${ }^{20}$ are coping with the onslaught of the socio-economic impact of globalization on their different societies. It is worth noting however that the concept of 'Global South' cannot be strictly linked to socio-economic problems affecting only those countries that exist in South of the equator." 21

The contemporary church lives in multi-religious and multi-cultural contexts and new communication technology is also bringing the people of the world into a greater awareness of one another's identities and pursuits. According to Wes Granberg-Michaelson:

As Christianity continues to grow in Africa, Asia, and Latin America, by the end of this century, in 2100, Christians living in the global South and East will number 2.8 billion, and be about three times more than the 775 million Christians projected to be found in the global North. In many ways, we're witnessing a return of Christianity to the non-Western cultures of Asia and Africa, reflecting more the environments which first gave rise to the church. But now Christianity is embedded in hundreds of cultures and languages demonstrating an incredible diversity of peoples and places that have received its incarnational presence. ${ }^{22}$

The contemporary form of Western reformed identity appears to be trapped in an interstitial space between neoliberalism and neo-conservatism that is weakening its efficacy because of its inability to exercise critical distance

20 With the two exceptions of the economies of Australia and New Zealand,

21 Hewitt, R. Roderick, 2016. The Context of the Global South. pp. 473-483. In Kenneth Ross, Jooseop Keum, Kyriaki Avtzi and Roderick R. Hewitt, 2016. Ecumenical Missiology Changing Landscape and New Conceptions of Mission, (Regnum Books, WCC Publications Oxford and Geneva).

22 Granberg-Michaelson Wesley, 2015. “From Times Square to Timbuktu”, Wesley Lehigh Council of Churches Campbell Memorial Lecture \#1, DeSales University, p.3. [Online] Available: http://lehighchurches.org/wp-content/uploads/2015/11/2015-Campbell-Lecture-1-transcript. pdf [Accessed October 1, 2017]. 
from their infectious and addictive ideology of greed. For the Reformed identity to serve as a life affirming agent for people living on the margins in this era, it must not only re-examine its close relationship with and seek authentic liberation from the enslaving ideologies of neoliberalism and neo-conservatism. Steven Metcalf describes neoliberalism as "the reigning ideology of our era - one that venerates the logic of the market and strips away the things that make us human." ${ }^{23}$ This theoretical conception argues for 'entrepreneurial freedoms and skills through a framework committed to private property rights, free market and free trade'24 The neo-liberal economic agenda "deregulation of economies around the world, for forcing open national markets to trade and capital, and for demanding that governments shrink themselves via austerity or privatization." ${ }^{25}$ Linked to the policies of the IMF and the 1980's policies of Reagan and Thatcher that helped to shape the ideal of society as a kind of universal market. ${ }^{26}$ This ideology was unleashed on many nations in the Global South, especially with Africa with its unstable economies. Neoliberalism requires that democratic institutions and systems of governance be controlled to serve the interest of a free market and is protected by laws to ensure that every aspect of democratic politics, from the choices of voters to the decisions of politicians, must be submitted to a purely economic analysis. The anti-imperialist religio-cultural movement of Rastafari has classified the strategic marriage between democracy and the neo-liberal economy as "poly-tricks". ${ }^{27}$

Democracy in the contemporary neoliberal model functions like a bubble in a very delicate state of existence that can easily burst and have its lifesustaining contents spilt." ${ }^{28}$ Neoliberalism seeks to define human beings

23 Metcalf Stephen 2017. Neoliberalism: the idea that swallowed the world. [Online] Available: https://www.theguardian.com/news/2017/aug/18/neoliberalism-the-idea-that-changed-theworld

24 Konkol, E. Brian 2017. Mission as Accompaniment - A Response to Mechanistic Dehumanization. Fortress Press: Minneapolis. pp. xii.

25 Metcalf Stephen 2017. Neoliberalism: the idea that swallowed the world.

26 Ibid.

27 Afari, Y., 2007. Overstanding Rastafari. Senya-Cum: Kingston. pp. 217-221.

28 Hewitt, R. R. 2014. Spirituality for democracy: Spiritual resources for democratic participation in the $21^{\text {st }}$ century. Verbum et Ecclesia, AOSIS Publishing Services, Cape Town. 
by the self-serving interest of the market. Billionaires and their large corporate lobby networks seek control over national governments and their policies to protect themselves from the constraints of democracy, from paying fair taxes, following environmental rules and paying living wages to their workers. Removal of political red tape and de-regularization of key rules of good governance allow big corporations to make their own rules without being accountable to the people of the land. Through their insatiable appetite for acquiring more, they become dysfunctional, and governments use taxpayers' money to bail out the companies and mortgage the nation's future wellbeing. The ultimate objective of neoliberalism is the removal of political and economic power from the majority of God's people. Konkol argues that the source and sustainer of neoliberal economic order is mechanistic dehumanization that according to Nick Haslam strip others of their life and dignity, because human beings are viewed as a means to an end..$^{29}$ This economic order within the context of postcolonial Empire has deified the market's grand epistemological claim - that the market is all-knowing and transcendent. According to Harvey Cox, the market is a god! Paul Tillich characterized the contemporary relationship between capitalism argues that capitalism and religion has become demonic and argues that "The technique of capitalism cannot be isolated from the demonic. What gives the demonic its depth is precisely the way in which it in-separately unites the rational and the anti-rational within itself." ${ }^{30}$ It has become comfortable and passive with privileges of proximity to the centres of power and has therefore lost it capacity to blush and be angry with systemic oppression against those on the margins. It is to this enslaving ideology of liberal capitalist modernity that this paper argues, the reformed identity has become seduced and must urgently emancipate itself from its deadly and fatal impotent entrapment.

29 Konkol, E. Brian 2017. Mission as Accompaniment - A Response to Mechanistic Dehumanization. Fortress Press: Minneapolis. pp 18, 202.

30 Tillich, Paul, 1989: The Demonic: A Study in the Interpretation of History, in: Jaquelyn Ann K. Kegley (ed.), Paul Tillich on Creativity. London: University Press of America. pp. 63-91. 


\section{Ineffectiveness of liberal theology to meaningfully address contemporary threats to life}

The compromising link of reformed theological and ecclesial identity to the neoliberal economic order has called into question the need to examine whether its close alliance with Liberal Theological tradition and Politics of the Left is contributing to the rise of nationalism and neoconservatism, global, political, economic and religious agenda. In this age of growing uncertainty people are no longer trusting humanistic theologies that are unable to offer tangible hope, explain and overcome forces of evil, find practical solutions for economic deprivation and offer miraculous divine intervention to their cries of pain. In centres of political and economic power that influence the populist governments of the Right, there is an abandonment of liberal theology for another religious worldview that gives meaning to their daily life. Increasingly people are dismissing liberal theological views of life as soft, weak and unconvincing response to people's security fears linked to religious extremism, Islamic terrorism and immigration. The political left were dismissed as irrelevant to the postmodern era with no sustainable solutions to the contemporary challenges. ${ }^{31}$ Reformed liberal theology has over the years tacitly accepted social democracy that embraced openness and tolerance that has resulted in disengagement and disenchantment with political and religious statusquo. This has created a broad space for the rise of identity populist politics that majored in being anti-establishment, isolationist, repudiation of the left and abandonment of political correctness. However, people viewed them as a better alternative to those pedalling an agenda of maintaining the status quo of the establishment. ${ }^{32}$

A bold attempt was made in 2004 by the World Alliance of Reformed Churches at its (WARC) 24th General Council in Accra, Ghana to confront the neoliberal economic order and its impact on people especially those that lived on the margins. It adopted The Accra Confession that "was based on the theological conviction that the economic and environmental injustices of the global economy required the Reformed family to respond as a matter

31 Hewitt, R, Roderick, 2017. The Church as Christ's Broken Body responding to the Emerging Global challenges in a Divided World. Unpublished paper, University of Kwa Zulu Natal, Pietermaritzburg, pp. 8.

32 Ibid. 
of faith in the gospel of Jesus Christ"33 in the face of economic injustice and ecological destruction. The confession was also adopted by the World Council of Churches (WCC) and The Council for World Mission (CWM):

“... reject the current world economic order imposed by global neoliberal capitalism and any other economic systems, including absolute planned economies, which defy God's covenant by excluding the poor, the vulnerable and the whole of creation from the fullness of life. We reject any claim of economic, political and military empire which subverts God's sovereignty over life and acts contrary to God's just rule." 34

The term empire was used to describe,

"The convergence of economic, political, cultural, geographic, and military imperial interests, systems, and networks for the purpose of amassing political power and economic wealth. Empire typically forces and facilitates the flow of wealth and power from vulnerable persons, communities, and countries to the more powerful. The Bible is full of stories of empires rising, over-extending, and falling. Empire today crosses all boundaries, strips and reconstructs identities, subverts cultures, subordinates nation states, and marginalizes or co-opt religious communities." ${ }^{35}$

This ecumenical process initiated by the Reformed Community that created the Accra Confession has created some conscientization for churches to relate their faith to the global effects of neoliberal capitalism, but the Reformed Community has not moved on to question the accompanying neoliberal reformed theology that has served to support the neoliberal economic order. Therefore, to a great extent, this Accra Confession, in spite of its acclaimed bold stand that matters of economic and environmental justice are essential to faith in Jesus Christ and the mission of the church and its rejection of the imperial environment in which neoliberalism rules the world's economy, not much has changed because the churches have not disengaged their investments from the economic system of empire.

33 The Accra Confession, 2007. The North American Covenanting for Justice Working Group, RCA Communication and Production Services.

34 Ibid., pp. 4.

35 Ibid. 


\section{The rise of neo-conservatism and prosperity gospel}

The contemporary era of global Christianity has entered a new phase in which certain types of conservative brands of evangelical Christianity have become allied with extreme nationalistic political and economic forces promoted by populist and amoral political leaders. It has resulted in deep public disappointment with those that bear the name Christian and church, because of their commodification of the gospel and ineffective public engagement with issues that deny millions the fullness of life. In some contexts in the global South some types of reformed identity and witness has embraced the populist wave that pedals a brand of Christianity called "prosperity gospel". The Lausanne Theology Working Group has defined Prosperity Gospel as "the teaching that believers have a right to the blessings of health and wealth and that they can obtain these blessings through positive confessions of faith and the 'sowing of seeds' through the faithful payments of tithes and offerings" ${ }^{36}$ This perspective on the symbiotic relationship between faith and economic prosperity has resulted in a type of pornification of Christianity especially by leaders addicted to greed because of their insatiable appetite for the gratification of desire.

The close link between reformed identity and neoconservative Christianity, is closely allied to the swing in the political landscape towards neoconservative world political order. This conservative expression of evangelical Christianity though its addiction to economic prosperity, promotes a prosperity gospel that has resulted in the pornification of Christianity that seeks to satisfy the instant gratification desires of people for quick wealth and health by unethical and deceptive miraculous methods. ${ }^{37}$ The gospel is usually compromised as close working partnership is arranged with governments to protect their religious and economic interest and in return they use the Christian faith to bless and support the work of the government. When reformed identity falls for this deceptive system of governance and is unable to keep its critical distance, then it runs a deep risk of losing its authenticity.

36 The Lausanne Theology Working Group, Statement on the Prosperity Gospel 2010. [Online] Available: https://www.lausanne.org/content/a-statement-on-the-prosperity-gospel

37 Ibid. 


\section{Reformed theological identity caught in a liminal space}

The Reformers' emphasis on the absolute sovereignty of God over all creation and the centrality of Scripture as preeminent authority in life of faith and the life of the church, directly place on the missional agenda of the church, the place and role of context and culture in reformed hermeneutics. The classical reformed theology bequeathed an exegetical method of interpretation (grammatical-literary-historical-theologicalcanonical) that was rooted, legitimized and self-proclaimed as orthodox within the context of European enlightenment. Therefore, all other contextual models/methods of focus on the Word requires focus on different cultural permutations in which the Word will be accessed, Biblical interpretation and every tradition is and has always been cultural interpretation..$^{38}$ Reformed theology is rooted in paradox, because of inherent tension in its locus of authority. It is caught in a liminal space between certainty and uncertainty. According to Blount ${ }^{39}$ the reformed identity participates in the struggle to overthrow false authority, yet in the case of South Africa the church became divided because it opted to be on both side of the justice divide as a defender of apartheid and also an opponent.

\section{The way forward}

The new resources for resistance/re interpretation/reconstruction of reformed theological identity must emancipate itself from its European contextual birth and childhood identity and grow up to reveal the richness of its global and contextual diverse identities. The Euro-centric philosophy of rationality that undergirded the theological formulations and expressions for the past 400 years and more have given European worldview a stranglehold on how reformed theology and identity are constructed. The way forward, especially for reformed theological identity in the Global South, necessitates that whilst one will not stop reflecting on the works of the classical Reformers, increased attention must be given

38 Blount, K. Brian, 2007. Reading Contextually as Reading Reformed, in Reformed Theology: Identity and Ecumenicity II, (Reading Contextually as Reading Reformed pp. 43-57), W B Eerdmans Publishing.

39 Ibid. 
to reconstructing the reformed identity in the Global South by drawing upon sounds, art, music and narratives of the common people from the underside of history. This paper proposes four areas of movement in order for the reformed theological identity to rediscover its authenticity in this postmodern era.

Firstly, a rediscovery of the priesthood of believers that incorporates the theological and missional insights of the special giftedness of the laity especially those on the margins, to carrying out the mission of God. The reformed heritage of being the church, defines its identity more in terms of governance and doctrine rather than in terms of the missional purpose of what the church is called to be and do. ${ }^{40}$ This has resulted in a clergy model that serves inner ecclesial needs of the church and contributing to the deskilling of the local church to fully participate in its ministry and mission. Lotter and Van Aarde have argued that the task of the clergy in preparing the laity is that of the priestly role of equipping and empowering them to be sent out into their neighbourhoods. ${ }^{41}$ The future of reformed identity therefore necessitates entering into a radical process of missional accompaniment with those that live on the margins. Konkol describes accompaniment as:

A theology of mission that promotes journeying together in a solidarity that practices independence and mutuality. Accompaniment which is found in the New Testament is expressed as Koinonia, is rooted in a God-human relationship in which God accompanies humankind in Jesus Christ through the Holy Spirit. Mission as accompaniment...guides mission into a "relational mode" among global companies that implies "proximity to the walking companion" and "accepting the invitation to accompany the other". ${ }^{42}$

Secondly, cultural reformed interpretation and multi-cultural constituencies. Kaiser posits that cultural interpretation should be

40 Hewitt, Church and Culture p. 156.

41 Lotter, G. \& van Aarde, T., 2017. A rediscovery of the priesthood of believers in Ephesians 4:1-16 and its relevance for the Missio Dei and a biblical missional ecumenism, In die Skriflig 51(2), a2251. https://doi. org/10.4102/ids.v51i2.2251

42 Konkol, Mission as Accompaniment, p xiii. 
recognized as a crucial part of the reformed essence..$^{43}$ This necessitates that the reformed theological identity revisits the role of language in the construct of its theology. According to Blount, culture creates the voice that is needed to decode sounds because it is only when words are accessed that they become meaningful and meaningful choice depends upon context. ${ }^{44}$ The construct of reformed faith and practice have not demonstrated a specific openness to contextuality. The renewal of reformed theological identity therefore necessitates an in-depth re-examination of the cultural space that one occupies in order to determine how and what text and language means. For many years, Reformed theology exegesis has been constructed using European cultures as standard and normative. Yet, for many years, this dominant form of reformed interpretation deceptively communicated that it was immune from cultural influences. The 'dominant' Reformed theology of the West is therefore contextual theology (shaped by environmental realities of the context) and therefore open to critique because contextual conclusions became objective/universal conclusions.

Thirdly, the renewal and relevance of reformed identity necessitates Pentecostal appropriation (Spirit of life) of its life-affirming Westminster Confession $^{45}$ that identified worship, glorify and enjoying God forever as central to the human identity. For people on the margins, spiritual formation is built on worship that Calvin classifies as the only goal of all the activities of this life. ${ }^{46}$ Within reformed worship the central focus is on allegiance to the mission of the triune God who is at work within the world ensuring that justice is at the heart of all social relationships. If enjoyment of God occupies a central place in reformed theology then it must re-examine the stranglehold veto powers that European cultural hermeneutics hold on reformed theology. There is an urgent need for theological and missional re-positioning for cultural balance. The shift in

43 Kaiser, C. 1998. The nature of the Church from a Reformed Perspective. Theological Review 19, no 1, p. 74.

44 Blount, K. Brian, 2007. Reading Contextually as Reading Reformed, in Reformed Theology: Identity and Ecumenicity II. pp. 46.

45 The Westminster Confession, [Online] Available: http://graceandtruthrpc.org/wp-content/ uploads/2013/07/Westminster_Confession1647.pdf [Accessed October 4 2017].

46 Calvin, John. 2002. Institutes of the Christian Religion (Henry Beveridge (trans). Christian Classics Ethereal Library, Grand Rapids, MI, [Online] Available: http://www. ccel.org/ccel/calvin/institutes.html [Accessed October 4, 2017]. 
the centre of Christianity from the Global North to the Global South and East necessitates that in these areas where most of the world's population lives and majority of those that live on the margins of political economic and religious power. Reformed theology must rediscover its theology of transformative social relationship engagement within the experiences and struggles of the margins. Since reformed confessions offer clues on cultural interpretations of faith and how scripture has been understood and changed to respond to new social situation, there should be no excuse for the reformed identity not responding to contemporary communal voices from the margins whose voices are not registered or acknowledged because of their diverse cultural locations.

Fourth, the propensity of reformed churches to divide because of controversies over leadership and doctrine has weakened their missional potential in nations of the South. However, even when they unite and some have taken the journey into union, it was largely motivated by structural survival of the institution that was experiencing economic stability of their dysfunctional ministries. ${ }^{47}$ The opportunity was not grasped to respond to the call for unity as an opportunity to restructure and renew the church for radical missional engagement with the challenges from their local political and socio-economic context. There is an urgent need for reformed identity to rediscover the unity of the Church among people living on the margins that are experiencing threats to life. The growing conflicts and divisions in the world and the growing wave of global people movement has been triggered by migration, refugees, and civil wars call for a missional response that required united missional ecclesial effort. When people move for whatever reasons, the church is also on the move, therefore the missional relevance of the Reformed identity for people living on the margins necessitates overcoming ecclesial divisions in order to foster unity that facilitates fullness of life. Reformed identity is therefore authenticated by the character of the practitioners who offer pastoral and missional leadership with ordinary

47 Hewitt, R. Roderick, 2012. Church and Culture.pp. 138. 


\section{Conclusion}

This reflection on the reformed identity and mission from the margins has argued that Reformed theology has the capacity to be liberative and transformative on one hand and on the other hand, enslaving and life denying. The death of the reformed identity is therefore assured when it ends up with unquestioning certitude about issues of life and faith without being open to honest and critical engagement of the text and context. The radical contextual and missional engagement of Calvin and other Reformers from his school of thought in fashioning reformed theological identify happened because they took seriously the task of listening and reflecting on the threats to life for people in their context that lived on the margins. The paper also argued that the evolution of Reformed identity has be caught in a liminal space between certainty and uncertainty because of how it has sought to face up to the challenges of justice issues. However in this postmodern era of the Reformed identity, the most threatening challenge to its authenticity comes through its uncritical alliance and allegiance to either neoliberalism or neo conservative theological and economic discourses. The future of the Reformed identity calls for a radical re-engagement with people who live on the margins who are experiencing many threats to life:

- Those who are suffering on account of and struggling against the cultures of racism and casteism, both of which-by holding them as inferior and unworthy, denying them the right to live with dignity and deprive them of "life in all its fullness".

- The indigenous peoples who struggle for identity, their homelands, their language and for survival amidst displacement and dispossession.

- People living with disabilities who struggle for a life with dignity and participation; and

- The migrant communities, and people who are forced out of their countries and communities on account of dispossession caused by human aggression and greed, and who are treated as the unwanted "others." 


\section{Bibliography}

Afari, Y 2007. Overstanding Rastafari. Kingston: Senya-Cum.

The Accra Confession 2010. Developed and published by the North American Covenanting for Justice Working Group, p. 4. [Online] Available: http://d3n8a8pro7vhmx.cloudfront.net/unitedchurchofchrist/legacy_ url/6049/Accra-new-final.pdf?1418430421

Bediako, Kwame 1999. Theology and Identity. Oxford: Regnum Books.

Blount, K B 2000. Reading Contextually as Reading Reformed, in Wallace M Alston Jr \& Michael Welker (eds.), Reformed Theology, Identity and Ecumenicity II, Biblical Interpretation in the Reformed Tradition, William B Eerdmans Publishing Company: Grand Rapids, Michigan; Cambridge, UK.

Calvin J Henry (Translator), 2002. Institutes of the Christian Religion. Beveridge, Christian Classics Ethereal Library, Grand Rapids, MI. [Online] Available: http://www.ccel.org/ccel/calvin/institutes.html

Douglass, D Jane 1996. A Reformed Perspective on the Ecumenical Movement. [Online] Available: http://www.religion-online.org/showarticle. asp?title $=421$

Graham, Judith 1990. The Slave Fortresses of Ghana. [Online] Available: http://www.nytimes.com/1990/11/25/travel/the-slave-fortresses-of ghana. html?pagewanted $=$ all\&mcubz $=0$

Granberg-Michaelson, Wesley 2015. From Times Square to Timbuktu. Wesley Lehigh Council of Churches Campbell Memorial Lecture \#1, DeSales University, [Online] Available: http://lehighchurches.org/wp-content/ uploads/2015/11/2015-Campbell-Lecture-1-transcript.pdf

Grenz, J Stanley and Olson, Roger E 1992. 20th Century Theology-God \& the World in a Transitional Age. InterVarsity Press, Illinois.

Hendricks, M, Obery, Jr. 2006. The Politics of Jesus. Doubleday: New York.

Hewitt R Roderick 2012. Church and Culture, an Anglo-Caribbean Experience of Hybridity and Contradiction. Dorpspruit: Cluster Publications. 
Hewitt, RR 2014. Spirituality for democracy: Spiritual resources for democratic participation in the 21st century. Verbum et Ecclesia.

Hewitt, R Roderick 2016. The Context of the Global South. In Kenneth Ross, Jooseop Keum, Kyriaki Avtzi and Roderick R Hewitt 2016. Ecumenical Missiology Changing Landscape and New Conceptions of Mission, Oxford, Geneva: Regnum Books, WCC Publications.

Hewitt, R Roderick 2017. "The Church as Christ's Broken Body Responding to the Emerging Global Challenges in a Divided World". HTS Teologiese Studies/Theological Studies 73 no. 3: https://doi.org/10.4102/hts. v73i3.4648

Kaiser, C 1998. The nature of the Church from a Reformed Perspective. Theological Review 19, no 1.

Keum J (ed.) 2012. Together Towards Life. Geneva: World Council of Churches Publications.

Koffeman, LJ 2015. "Ecclesia reformata semper reformanda." Church renewal from a Reformed perspective, HTS Teologiese Studies/ Theological Studies 71(3), Art. \#2875, 5 pages. [Online] Available: http:// dx.doi.org/10.4102/hts.v71i3.2875 [Online] Available: https://repository.up.ac.za/ bitstream/handle/2263/50939/Koffeman_Ecclesia_2015.pdf;sequence=1

Konkol, E Brian 2017. Mission as Accompaniment-A Response to Mechanistic Dehumanization. Minneapolis: Fortress Press.

Manchala, Deenabandhu 2012. Mission from the margins, toward a just world, International Review of Mission, Geneva. [Online] Available: http://onlinelibrary.wiley.com/doi/10.1111/j.1758-6631.2012.00092.x/full

Metcalf, Stephen 2017. Neoliberalism: the idea swallowed the world. [Online] Available: https://www.theguardian.com/news/2017/aug/18/ neoliberalism-the-idea-that-changed-the-world

Pillay, J 2017. Faith and reality: The role and contributions of the ecumenical church to the realities and development of South Africa since the advent of democracy in 1994, HTS Teologiese Studies/ Theological Studies 73(4), 4519, p.1. [Online] Available: https://doi. org/10.4102/hts.v73i4.4519 
Ross, Kenneth; Keum, Jooseop; Avtzi Kyriaki and Hewitt, R Roderick 2016. Ecumenical Missiology Changing Landscape and New Conceptions of Mission. Oxford and Geneva: Regnum Books, WCC Publications.

Tillich, Paul 1989. The Demonic: A Study in the Interpretation of History. In Jaquelyn Ann K Kegley (ed.), Paul Tillich on Creativity. London: University Press of America. 63-91.

The Historical Centre (Fredrick Engles House and the Museum of Early Industrialisation). [Online] Available: http://www.erih.net/i-wantto-go-there/site/show/Sites/historical-centre-engels-house-and-museum-of-earlyindustrialization/

The Lausanne Theology Working Group, Statement on the Prosperity Gospel 2010. [Online] Available: https://www.lausanne.org/content/astatement-on-the-prosperity-gospel

Wickeri, L Philip 2004. Mission from the Margins: The Missio Dei in the Crisis of World Christianity. Presbyterian Church (U.S.A.). A Corporation on behalf of the Office of Theology and Worship, Louisville, KY. 